Journal of Southeast Asian

\title{
A Special Tribute to Anne Frank of the Southeast Asian Archive at the University of California, Irvine
}

\author{
Wayne E. Wright \\ University of Texas, San Antonio, wewright@purdue.edu \\ Linda Trinh Vo \\ University of California, Irvine, volt@uci.edu \\ Caroline Kieu Linh Valverde \\ University of California, Davis \\ Nhi Lieu \\ University of Texas, Austin \\ Rifka Hirsch \\ Former Executive Director of The Cambodian Family
}

See next page for additional authors

Follow this and additional works at: https://docs.lib.purdue.edu/jsaaea

Part of the Asian American Studies Commons

\section{Recommended Citation}

Wright, Wayne E.; Trinh Vo, Linda; Kieu Linh Valverde, Caroline; Lieu, Nhi; Hirsch, Rifka; Vu, Roy; Pelaud, Isabelle Thuy; and Pfeifer, Mark E. (2008) "A Special Tribute to Anne Frank of the Southeast Asian Archive at the University of California, Irvine," Journal of Southeast Asian American Education and Advancement: Vol. 3 : Iss. 1 , Article 5.

DOI: 10.7771/2153-8999.1101

Available at: https://docs.lib.purdue.edu/jsaaea/vol3/iss1/5

This document has been made available through Purdue e-Pubs, a service of the Purdue University Libraries. Please contact epubs@purdue.edu for additional information.

This is an Open Access journal. This means that it uses a funding model that does not charge readers or their institutions for access. Readers may freely read, download, copy, distribute, print, search, or link to the full texts of articles. This journal is covered under the CC BY-NC-ND license. 
A Special Tribute to Anne Frank of the Southeast Asian Archive at the University of California, Irvine

\section{Authors}

Wayne E. Wright, Linda Trinh Vo, Caroline Kieu Linh Valverde, Nhi Lieu, Rifka Hirsch, Roy Vu, Isabelle Thuy Pelaud, and Mark E. Pfeifer 


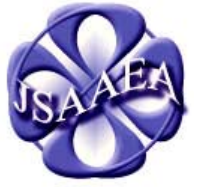

Volume 3

\section{Education \& Advancement \\ WWw.JSAAEA.org \\ A Special Tribute to Anne Frank of the Southeast Asian Archive at the University of California, Irvine}

Journal of Southeast Asian American
A peer-reviewed

scholarly journal

published by the

National Association

for the Education \&

Advancement of

Cambodian, Laotian, and Vietnamese Americans (NAFEA)

\section{Editor's Introduction}

The Journal of Southeast Asian American Education and Advancement (JSAAEA) is pleased to publish this tribute article recognizing one of the great contributors to the interdisciplinary field of Southeast Asian American Studies-Anne Frank. As many readers may know, Anne was the founding librarian of the Southeast Asian Archive at the University of California, Irvine (see http://www.lib.uci.edu/libraries/collections/sea/sasian.html). Anne has also been serving as a special advisor to JSAAEA, and has lent her support and expertise to other journals in the field.

As described on the UC Irvine Library Website, the Southeast Asian Archive, established in 1987 "collects materials relating to the resettlement of Southeast Asian refugees and immigrants in the United States (and to a lesser extent, worldwide), the boat people and land refugees, and the culture and history of Cambodia, Laos, and Vietnam.” The Archive includes "books, refugee orientation materials, government documents, reports and surveys, periodicals, journal articles, newspaper clippings, video and audio recordings, ephemera, personal and institutional papers." One can also find at the Archive copies of any and all theses and dissertations related to the Southeast Asian communities. In short, the Archive is a literal treasure trove for students, scholars, community leaders, community members, and all others interested in Southeast Asian American Studies.

Anne is retiring after over 20 years of service to the Archive. Given her great service, we felt it appropriate to pay tribute to her work which has greatly benefitted numerous students, scholars, and community leaders and members, as well as the communities themselves. To do so, we invited several individuals from around the country who have benefited from the Archive and from Anne's expert assistance. Professor Linda Trinh Võ of UC Irvine, and a member of the Archive's Advisory Board, recommended several names of potential contributors to this tribute article. We contacted as many as we could, and were grateful that several responded and were willing and able to meet the short deadline. No doubt there are hundreds of individuals who would have been willing to contribute. We hope the tributes and stories below reflect similar experiences and feelings of all those who have had the pleasure of interacting with Anne while using the Archive, and that these tributes provide a small glimpse into the deep gratitude that exists for Anne and her work.

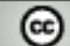

SOMERIGHISRESERVEDReaders are free to copy, display, and distribute this article, as long as the work is attributed to the author(s) and the Journal of Southeast Asian American Education \& Advancement, it is distributed for noncommercial purposes only, and no alteration or transformation is made in the work. More details of this Creative Commons license are available at http://creativecommons.org/licenses/by-nc-nd/3.0/. All other uses must be approved by the author(s) or JSAAEA. 
We wish for Anne a happy, relaxing, and well-deserved retirement. We thank her for legacy she is leaving behind which will benefit us for many years to come.

\title{
Anne Frank - The Consummate Archivist and Community Advocate
}

\author{
Linda Trinh Võ \\ University of California, Irvine
}

Librarian Anne Frank's name has become synonymous with the Southeast Asian Archive, so I am still becoming accustomed to the idea that she has actually retired. Undoubtedly, her connection with the Archive contributed to the postponement of her retirement, because the work was so rewarding and meaningful to her. Presently, the Archive has its own room in the University of California, Irvine's Langson Library, with additional original materials and artifacts housed in the Special Collections Department, but it initially started in one drawer of her file cabinet. Anne was there at the beginning in 1985 when Dr. Pham Cao Duong, along with Dr. $\mathrm{Vu}$ Dinh Minh, initiated the Archive collection of the refugee population. ${ }^{1}$ Those from Cambodia, Laos, and Vietnam were resettling en masse to the area and would eventually form the largest Vietnamese and Cambodian diasporic communities outside of their respective homelands. ${ }^{2}$ Over the years, she helped to create a network of scholars, librarians and archivists, media representatives, and community members across the country who share an interest in preserving the Southeast Asian American experience. She has labored tirelessly to acquire resources and materials for the Archive and to inform community members and organizations to donate materials to preserve their history and culture.

In many ways, Anne has been a dedicated ambassador who has traveled the country promoting the Archive at conferences, festivals, museums, and numerous educational and community sites, where many of us became familiar with her and the Archive. I first met Anne at an Association for Asian American Studies conference in the early 1990s when she handed me an Archive newsletter and invited me to visit the Archive. When I interviewed for the faculty position at UC Irvine, I finally had the opportunity to peruse the Archive and realized that it was a real treasure trove, and like her numerous converts, have been committed to nurturing its growth. Since the materials in the collection, such as the books, dissertations, journal articles, periodicals, reports, and ephemera, are accessible in one room, the Archive has been invaluable for students in my Asian American Studies courses, and for students across campus planning to conduct research projects on refugees and immigrants. Undergraduate and graduate students and scholars from across this country and from other nations utilize the Archive to conduct research on social, cultural, political, economic, religious, and educational topics. Anne was always so welcoming of every visitor, whether they were a student or renowned scholar, ensuring that they had the materials they needed, and she was even willing to come in on weekends to accommodate visiting researchers who had limited time to complete their research.

Anne has a keen ability to navigate the political terrain of the community, by being cognizant of the controversies, as well as by recognizing that documenting refugee histories and collecting resources from displaced populations means being innovative and patient. Yet she 
willingly assumed these tasks with such enthusiasm, writing her own job description along the way, which is precisely why she is so irreplaceable. Given her tendency to put others first, few know of her contributions as a community advocate on behalf of Southeast Asian Americans, as well as other groups. She has been active with the Refugee Forum of Orange County and the California State Refugee Forum, which are an inter-agency groups that facilitate refugee resettlement through building networks and information sharing, and is a board member of the Orange County Asian and Pacific Islander Community Alliance, which provides service, education, advocacy, organizing, and research programs that are inclusive of Southeast Asian Americans of multiple generations. In addition, she collaborated with educators and community members to produce, "The Vietnamese American Curriculum Project," which is available on the Internet and can be utilized by teachers. ${ }^{3}$ Her knowledge of the needs of the population prompted her to become involved in community outreach and engagement projects, and the Archive gained immensely from her efforts to bridge the university with the larger community.

With the Southeast Asian Archive, Anne has left a profound legacy that future generations can benefit from, and more importantly, she has been instrumental in recovering and recording the history of our communities, which have prevailed despite the personal and political heartaches and losses we have endured. I also appreciate Anne's friendship and all she has taught me about archival work. Moreover, I truly miss walking a few buildings away to visit her at the Archive. I am pleased to know that we can still carpool to community meetings and events, for even in retirement, she remains committed to community causes, between her many travels around the globe.

\footnotetext{
${ }^{1}$ See for more information about the Archive, Dorothy B. Fujita-Rony and Anne Frank, “Archiving Histories: The Southeast Asian Archive at University of California, Irvine.” Amerasia Journal 29:1 (2003): $153-164$.

${ }^{2}$ Little Saigon officially encompasses the cities of Westminster, Garden Grove, and Santa Ana in Orange County and Cambodia Town, which is also known as Little Phnom Penh or Little Cambodia, is situated in Long Beach located in Los Angeles County.

${ }^{3}$ See: http://www.tolerance.org/teach/web/vietnamese/contributors.jsp
}

\title{
Assisting an Insecure Graduate Student
}

\author{
Wayne E. Wright \\ University of Texas, San Antonio
}

I first met Anne in the early 1990s as a young graduate student at California State University, Long Beach, working on my MA-Thesis related to language and education policy for Cambodian American students in the Long Beach Unified School District. Given how little had been published on Cambodian Americans, I was thrilled to find out from a colleague about the Southeast Asian Archive at UC Irvine. I admit to being a bit nervous when I first entered the Archive. I felt a little out of my league. I was a $2^{\text {nd }}$ grade teacher attending a Cal State school, and here I was at a University of California campus attempting to be a serious scholar. I quietly wondered to myself if I was really allowed to be there and if I would be chased out by the real scholars. Anne greeted me warmly as I walked in and immediately put me at ease. After brief 
conversation about my research interests, Anne gave me a tour of the Archive, and pointed me towards a treasure of resources relevant to my thesis research. I felt like a kid in a candy shop. I couldn't believe the amount and diversity of the resources in there. I marveled at the types of ephemeral materials available one would not ordinarily expect to find in a university library programs from cultural shows put on by local Cambodian student associations, documents produced by local school districts and community organizations, clippings from newspaper articles, video and audio recordings, and much more. I couldn't believe I was allowed full access to these materials. It took some discipline to stay focused on my research and not just get lost exploring all the interesting materials I came across. I returned to the Archive many times, and spent many hours at the copy machine. During each visit I received a personal greeting from Anne who showed real interest in my research, and who always had helpful suggestions for relevant materials. At the completion of my research, I was proud to donate a large box of materials I had gathered over the years from my research and involvement with the Cambodian community in Long Beach. Prior to visiting the Archive, I had little understanding of the value these materials I hoarded over the years as personal keepsakes. Anne was absolutely thrilled to receive them, and it was gratifying to know they were safe in the Archive where they would help preserve history and be a resource to others.

Since leaving California, I have had the pleasure of running into Anne and chatting with her on occasion at different conferences. I always looked forward to receiving her Southeast Asian Archive Newsletters listing in great detail recent acquisitions. I always admired how she would acknowledge each donor by name with a list of each resource they contributed. No contribution was too small to be recognized. Since the launch of this journal, Anne's newsletters have proved instrumental in helping us identify current and up-and-coming scholars to serve as editorial review board members and as contributors to the journal. The attention Anne has brought to JSAAEA through the Archive newsletter by announcing our calls for papers and publications has been of great assistance to our journal. Her association with the journal as a special advisor and her assistance with promoting it helped to give JSAAEA immediate credibility. Anne will be greatly missed, but the legacy she leaves behind with the Archive she helped build into such an invaluable resource will continue to be of great benefit for generations to come.

\title{
A Tribute to Anne Frank
}

\author{
Caroline Kieu Linh Valverde \\ University of California, Davis
}

Anne Frank represents for me all that is good about our field of Southeast Asian American Studies. She not only offers us a plethora of research information through the Southeast Asian Archive, she also has a direct lifeline to our work and manages to connect us from far away places. I am most of all grateful for her generosity and encouraging nature throughout my academic career. 
Whatever you can imagine to exist in terms of research material, she has it or knows exactly where to get it for you. Who knew in 1996 that I could find reports on Israeli overseas Vietnamese experiences?! She had several of these rare writings filed away, right next to stories of Vietnamese in places like Germany and Russia. Her diligence in gathering data, even the most obscure ones, motivated me to save all my original documents on Amerasians. I eventually donated my collection of Amerasian research materials from 1980s-2000 to the Southeast Asian Archive for future scholars to move this research forward.

Anne's diligence in finding information extends beyond texts. For instance, it has always intrigued me how she managed to learn of our research, sometimes even before we are aware of it, such as making interdisciplinary connections for us through casual correspondences. From our interactions at conferences or through phone conversations, I knew with confidence that if someone was even thinking about a research project, she was, as the kids say, "all over it." This kind of vigilance contributed to the creation of a resource-rich Archive.

Her gift of learning about our research extended to her ability to connect us as scholars. Knowing the kinds of writings that complimented each other, she often suggested collaborative work and pin pointed interesting connections that would go unnoticed by isolated scholars. Under her leadership, the Southeast Asian Studies Archive grew to represent a center for scholars to come for research and networking, where they could assist fellow scholars and, where scholars could learn from each other.

Anne Frank's contributions over the years have been tremendous. She has established a wonderful synergy of mutual gathering and giving back of our academic works. For instance, Anne was able to send me extremely valuable research on my ao dai exhibit. So, I immediately thought to mail her the finished products when the exhibit finally showed. Anne offers this idea that giving begets good scholarship and that philosophy is what I most value about Anne. Her legacy is alive and well in the students she mentored and scholars she witnessed grow. She is everything good about academia and in particular Southeast Asian/Asian American Studies. Thank you, Anne.

\title{
A Tribute to Anne Frank
}

\author{
Nhi Lieu \\ University of Texas, Austin
}

As the founding archivist of the Southeast Asian Archive, Anne Frank played a critical role in documenting the histories of various Southeast Asian refugee and immigrant communities. She had an important vision that was complete and inclusive that supported not only academic scholarship but also studies conducted at the community level.

During her tenure, Anne showed tremendous support for scholars, particularly young scholars with creative and non-traditional projects. I recall meeting her for the first time in the mid-1990s when I was a graduate student starting my research. Having traveled from the 
University of Michigan, I was overwhelmed by the materials at the Archive. Anne immediately put me at ease and directed me to the sources I needed, but also provided much more informal knowledge and insight about the different Southeast Asian communities and their cultural and political practices. Anne always made sure that everyone who came to the Archive got what they needed; but more importantly, she extended her assistance to scholars who traveled long distances. She knew that I was a scholar who did not have direct contact with the local community, so she took time and energy to send me materials and updates on my topic of research. I will always be grateful to Anne for her generosity, which has also inspired me to give back to the Archive, whenever I am able.

To me, Anne's greatest contributions lie not only in her support of all of our research but also in her abilities to connect the scholars working on Southeast Asian American communities. Ever since I can remember, she has attended every conference at the Association for Asian American Studies and worked effortlessly to link scholars across the country. She also regularly attends community functions and events and continues to do so in her retirement. Anne Frank's efforts will always be appreciated and I am glad to have worked with such a visionary.

\section{Anne Frank’s Legacy}

\section{Rifka Hirsch \\ Former Executive Director of The Cambodian Family}

I've known Anne for a very long time, as a trusted colleague in the Orange County refugee program. When we first met, I was Executive Director of The Cambodian Family, and she was just starting her collection of materials for the Southeast Asian American Archive at UCI. She seemed a gentle and dedicated woman. Over the years, her quiet enthusiasm had its effect upon me and others who worked with refugees. She was an intimate part of the family. When we wanted someone highly principled and trustworthy to work with, we immediately thought of Anne, with her humble intelligence and unfaltering decency. Each time we had the opportunity to interact, it gave me pleasure and security to know of her involvement.

She loved working with refugees and documenting their experience. Nothing was too small for her collection. She found value in papers and publications which had long ago served their purpose for us. Instead of throwing them away, it was wonderful to pass them on to Anne. The way she accepted them, as if they were precious jewels, made us feel like benefactors. Anne had a way of transforming old paper into deep meaning, both for its reflection of the past and for its use for others in the future.

Anne is unique, both for her beautiful character and for her love of the refugee story, in all its aspects. Through her work and in the life she shared with us as colleagues, she has left a legacy that moves us. The Archive is her legacy, and all who spend time there will benefit from her work. The personal memories we hold of Anne are also her legacy. As I spend time remembering her, I feel enriched. It isn't often that you meet such a good human being in your life. Thank you, Anne, for your work and for sharing yourself with us. 


\title{
A Tribute to Anne Frank
}

\author{
Roy Vu \\ North Lake College
}

Ms. Anne Frank has played an integral role in finding invaluable sources during my research visits to the Southeast Asian Archive at the University of California at Irvine. Anne's immeasurable knowledge, diligence, resourcefulness, and enthusiasm were infectious in helping me find the necessary documents that would prove vital to my research on Vietnamese refugees and their community formation strategies. She made my visits a more enjoyable and fruitful research experience. I am always grateful for her assistance and guidance as I work on the publication of my manuscript. Already, Ms. Frank and the wonderful staff at the SEA Archive have proven to be enormously valuable in the completion of my doctoral dissertation, published essays, a museum exhibit, and several paper presentations for academic conferences.

Of equal importance, I have found a dear friend in Anne Frank who I have called upon to find a palatable Vietnamese restaurant and share a pleasant conversation as we feasted on delicious Vietnamese cuisine. Anne has always made me feel welcome in California whether it be digging through files at the SEA Archive or dining at a restaurant in Little Saigon. Current and future scholars will no doubt miss Anne Frank and her indomitable spirit to try and collect and preserve everything that is precious to Vietnamese American history. Thanks to her numerous contributions, she will always be remembered as a pioneer archivist and an endeared friend in the Vietnamese community. We can never thank her enough for giving us the opportunity to find our own history and our own voice as we continue to partake on this tremendous task in piecing together our past for future generations. Thank you Anne for finding things that we have lost on our journey to America. Individuals like yourself have made us feel a little more at home_-as a visiting scholar, as a citizen, and as a friend.

\section{A Tribute to Anne Frank}

\section{Isabelle Thuy Pelaud San Francisco State University}

I hope Anne Frank will enjoy her retirement and be able to look back at her career with great satisfaction. There are very few people that are liked by everyone for the right reasons: kindness, professionalism and calmness. I have been to the Archive a few times with vague ideas of what I was looking for and Anne always welcomed me. She took all my leads seriously and directed my research patiently, going through files and searching for obscures texts. I was always struck by her patience, diligence and her non-judgmental stance. When I met Anne at conferences, she always greeted me warmly. Her small gestures of inclusion, her paying attention to detail and her readiness to help have made a real difference for me as a person who used to be very shy in academic settings. 


\title{
Anne Frank’s Contributions to the Hmong Studies Journal and Hmong Studies Scholarship
}

\author{
Mark E. Pfeifer \\ Editor, Hmong Studies Journal
}

I would like to acknowledge Anne Frank's important role in the Hmong Studies Journal and in disseminating information about Hmong-related resources. Anne was a founder of the Hmong Studies Journal, an online peer-reviewed journal, along with Robin Vue-Benson in 1996. At this time, there weren't nearly the range of Hmong Studies research resources that exist today. It isn't exaggerating to say that for the past 12 years, the Hmong Studies Journal has played a pivotal and ongoing role in promoting research related to the Hmong in the United States and elsewhere. The journal has now published 10 issues and more than 60 scholarly, peer-reviewed issues and is now part of the EBSCO Academic Search Complete and ProQuest Ethnic News Watch databases. Anne has been involved with the journal's editorial team from the very beginning and she continues to play an important part as an editorial board member and Assistant Editor. The journal has contributed to the development of Hmong Studies as a field of inquiry and inspired many Hmong-origin graduate students to become active scholars. More than half of the articles published in the journal's history have had a Hmong-origin author.

Anne has also contributed to the Hmong Studies Journal and Hmong Studies more generally as a bibliographer. In the first five issues of the journal (published from 1996-2000), Anne published articles listing recent works published in Hmong Studies. These bibliographies contributed to knowledge of ongoing research in the field at a time when few other resources were available. Anne's bibliographies were published in Volume 1 (No. 1), Volume 1 (No. 2), Volume 2 (No. 1), Volume 2 (No. 2), and Volume 3. Anne's essential contributions to the Hmong Studies Journal may be viewed at the Journal's webpage:

http://www.hmongstudies.org/HmongStudiesJournal.html 




Volume 3

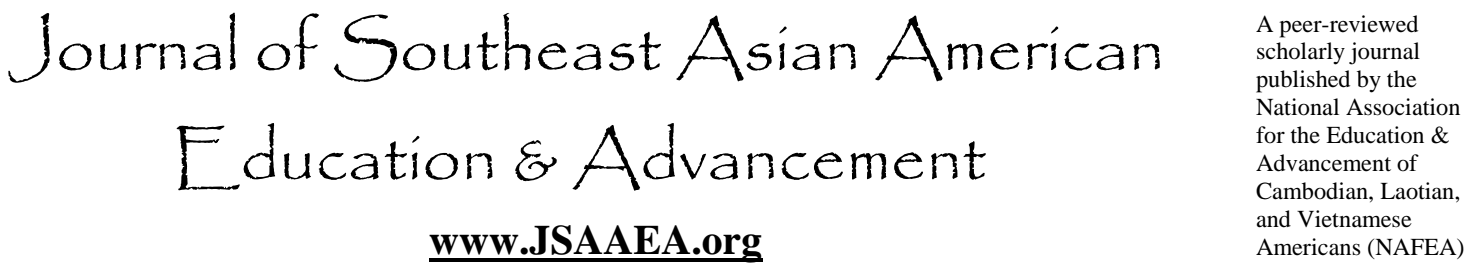

Editor

Dr. Wayne E. Wright

University of Texas, San Antonio

Associate Editors

Dr. Chhany Sak-Humphry

University of Hawaii

Dr. KimOanh Nguyen-Lam

California State University, Long Beach

Book Review Editor

Dr. Leslie Turpin

School for International Training

Creative Works Editor

Phouang Hamilton

Washington Office of Superintendent of Public Instruction

Special Advisor

Anne Frank

University of California, Irvine, Southeast Asian Archive

Editorial Assistant

Mariana Kuhl

University of Texas, San Antonio

Comments and questions for the editorial staff may be directed to jsaaea@lists.sis.utsa.edu

\section{Editorial Review Board}

\author{
Dr. Carl L. Bankston III \\ Tulane University \\ Dr. Phala Chea \\ Lowell Public Schools \\ Dr. Changming Duan \\ University of Missouri, Kansas City \\ Dr. Nancy H. Hornberger \\ University of Pennsylvania \\ Dr. Peter Nien-Chu Kiang \\ University of Massachusetts, Boston \\ Dr. Stacey Lee \\ University of Wisconsin, Madison
}

\author{
Dr. Pollie Bith-Melander \\ Asian and Pacific Islander Wellness Center \\ Dr. George Chigas \\ University of Massachusetts, Lowell \\ Dr. Sophal Ear \\ U.S. Naval Postgraduate School \\ Dr. Samlong Inthaly \\ Minneapolis Public Schools \\ Dr. Kevin K. Kumashiro \\ University of Illinois, Chicago \\ Dr. David Chanpannha Ley \\ Montgomery County Public Schools
}




\author{
Dr. Sue Needham \\ California State University, Dominguez Hills \\ Dr. Max Niedzwiecki \\ Daylight Consulting Group \\ Dr. Clara Park \\ California State University, Northridge \\ Dr. Loan T. Phan \\ University of New Hampshire \\ Dr. Karen Quintiliani \\ California State University, Long Beach \\ Dr. Fay Shin \\ California State University, Long Beach \\ Dr. Yer J. Thao \\ Portland State University \\ Dr. Khatharya Um \\ University of California, Berkeley \\ Dr. Terrence G. Wiley \\ Arizona State University
}

\author{
Dr. Bic Ngo \\ University of Wisconsin-Madison \\ Dr. Leakhena Nou \\ California State University, Long Beach \\ Dr. Mark Pfeifer \\ Texas A\&M University, Corpus Christi \\ Dr. Bounlieng Phommasouvanh \\ Minnesota Department of Education \\ Dr. Kalyani Rai \\ University of Wisconsin, Milwaukee \\ Dr. Nancy J. Smith-Hefner \\ Boston University \\ Dr. Myluong Tran \\ San Diego State University \\ Dr. Linda Trinh Vo \\ University of California, Irvine \\ Dr. Zha Blong Xiong \\ University of Minnesota
}

\begin{tabular}{|c|c|}
\hline \multicolumn{2}{|c|}{$\begin{array}{l}\text { Dr. Kou Yang } \\
\text { State University, Stanislaus }\end{array}$} \\
\hline \multicolumn{2}{|c|}{ Doctoral Student Editorial Review Board } \\
\hline $\begin{array}{c}\text { Keo Chea } \\
\text { University of Pennsylvania }\end{array}$ & $\begin{array}{c}\text { Vichet Chhuon } \\
\text { University of California, Santa Barbara }\end{array}$ \\
\hline $\begin{array}{c}\text { Loan Dao } \\
\text { University of California, Berkeley }\end{array}$ & $\begin{array}{c}\text { Annie BichLoan Duong } \\
\text { San Joaquin County Office of Education }\end{array}$ \\
\hline $\begin{array}{l}\text { Ha Lam } \\
\text { Arizona State University }\end{array}$ & $\begin{array}{c}\text { Ravy Lao } \\
\text { University of California, Santa Barbara }\end{array}$ \\
\hline $\begin{array}{c}\text { Vanna Som } \\
\text { Harvard University }\end{array}$ & $\begin{array}{c}\text { Rassamichanh Souryasack } \\
\text { University of California, Santa Barbara }\end{array}$ \\
\hline $\begin{array}{c}\text { Giang Pham } \\
\text { University of Minnesota }\end{array}$ & $\begin{array}{c}\text { Layheng Ting } \\
\text { State University of New York, Albany }\end{array}$ \\
\hline $\begin{array}{c}\text { Tinou Tran } \\
\text { University of Houston, Texas }\end{array}$ & $\begin{array}{c}\text { Loan Tran } \\
\text { University of California, Santa Barbara }\end{array}$ \\
\hline $\begin{array}{c}\text { Phitsamay Sychitkokhong Uy } \\
\text { Harvard University }\end{array}$ & $\begin{array}{c}\text { Yang Sao Xiong } \\
\text { University of California, Los Angeles }\end{array}$ \\
\hline
\end{tabular}

